\title{
Problematika Linieritas dan Pemenuhan Kualifikasi Akademik Guru dalam Lembaga PAUD
}

\author{
Milla Diah Putri Nazidah ${ }^{1 凶}$ \\ Pendidikan Guru Pendidikan Anak Usia Dini, Universitas Sebelas Maret \\ DOI: $10.31004 /$ obsesi.v6i2.1373
}

\begin{abstract}
Abstrak
Guru PAUD merupakan sosok peletak dasar pendidikan kedua setelah orang tua. Guru PAUD harus memiliki keahlian dalam bidang ini. Namun kenyataannya masih banyak guru yang belum memenuhi standar nasional. Tujuan penelitian ini untuk membahas problematika guru di lembaga PAUD yang meliputi kualifikasi akademik dan linieritas lulusannya. Penelitian ini menggunakan metode kualitatif pendekatan deskriptif, teknik yang digunakan yaitu observasi, wawancara, dan dokumentasi, analisis data dilakukan sejak pengumpulan data sampai kesimpulan. Hasil penelitian menunjukkan bahwa guru-guru di RA Bakti 7 Wonorejo tidak memenuhi standar nasional sebagai guru PAUD, hal ini diketahui dari lulusan setiap guru tidak ada yang relevan dengan bidang PAUD. Terdapat 4 guru dengan 2 orang S1 pendidikan umum dan 2 orang S1 pendidikan islam. Problematika yang terjadi yakni kurangnya SDM guru PAUD yang sesuai standar nasional, berdampak pada kualitas guru juga kualitas pendidikan di Indonesia. Kegiatan pengembangan guru melalui pelatihan menjadi upaya peningkatan kualitas kelayakan guru di lembaga ini.
\end{abstract}

Kata Kunci: guru; kualifikasi; linieritas; lembaga; PAUD.

\begin{abstract}
PAUD's teachers are the second basic laying figures of education after parents. PAUD's teachers must have expertise in this field. But in reality there are still many teachers who have not met national standards. The purpose of this research is to discuss the problems of teachers in PAUD's institutions which include academic qualifications and linearity of graduates. This research uses qualitative method of descriptive approach, techniques used is observation, interview, and documentation, data analysis is done from data collection to conclusion. The results showed that the teachers at RA Bakti 7 Wonorejo did not meet the national standards as PAUD's teachers, it is known from the graduates of every teacher that nothing is relevant to the field of PAUD. There are 4 teachers with 2 S1 public education and 2 S1 Islamic education. The problem is the lack of human resources of PAUD's teachers in accordance with national standards, impact the quality of teachers as well as the quality of education in Indonesia. Teacher development activities through training become an effort to improve the quality of teacher worthiness in this institution.
\end{abstract}

Keywords: teachers; qualification; linearity; institution; early childhood education.

Copyright (c) 2021 Milla Diah Putri Nazidah

$\square$ Corresponding author :

Email Address : millazee123@student.uns.ac.id (Surakarta, Indonesia)

Received 21 May 2021, Accepted 26 June 2021, Published 17 Desember 2021 


\section{PENDAHULUAN}

Penyelenggaraan layanan PAUD seiring berjalannya waktu semakin meningkat, hal ini dibuktikan dengan banyaknya jenis layanan PAUD yang diberikan oleh masing-masing lembaga PAUD sesuai dengan kebutuhan dan karakterisitik anak. Beragam variasi dan juga inovasi turut diberikan sehingga perkembangan munculnya lembaga PAUD mengalami peningkatan yang signifikan. Penyelenggaraan layanan PAUD ditujukan untuk mendukung tumbuh kembang anak usia dini dengan memberikan layanan/pembinaan melalui rancangan pendidikan agar dapat membentuk kesiapan anak dalam memasuki fase pendidikan selanjutnya (Zulkarnain \& Supriadi, 2021).

Salah satu kunci keberhasilan penyelenggaraan layanan PAUD yaitu adanya guru atau tenaga pendidik. Dalam undang-undang Republik No. Nomor 14 tahun 2005 tentang Guru dan Dosen, dalam pasal 1, dinyatakan bahwa guru adalah pendidik profesional dengan tugas utama mendidik, mengajar, membimbing, mengarahkan, melatih, menilai, dan mengevaluasi peserta didik pada pendidikan anak usia dini jalur pendidikan formal, pendidikan dasar, dan pendidikan menengah (Presiden RI, 2005). Guru juga merupakan pendamping sekaligus orang tua kedua bagi anak di lingkungan sekolah, orang tua melimpahkan tanggung jawab pendidikan anak masing-masing kepada guru di sekolah. Dapat diartikan bahwa guru bertanggung jawab terhadap perkembangan potensi anak dan pertumbuhan kemanusiaannya. Untuk mewujudkan tujuan pendidikan, guru PAUD sebagai peletak dasar/pondasi pendidikan kedua selain orang tua, maka guru PAUD harus memiliki peran strategis untuk penguatan anak dalam pendidikan (Esterina, 2020). Sehingga peran guru PAUD tidak dapat dimiliki oleh sembarang orang melainkan harus memenuhi standar nasional yang telah ditetapkan dengan latar belakang pendidikan sesuai bidang pendidikan anak usia dini. Guru PAUD harus memenuhi kualifikasi akademik yang sudah ditentukan, salah satunya yaitu pemenuhan kompetensi guru. Sesuai yang tertera dalam Peraturan Menteri Pendidikan dan Kebudayaan RI No. 137 tahun 2014 tentang Standar Nasional Pendidikan Anak Usia Dini tentang kompetensi yang harus dikembangkan secara utuh oleh guru PAUD mencakup kompetensi pedagogik, kepribadian, sosial, dan profesional dengan kualifikasi akademik guru PAUD minimal memiliki ijazah Diploma empat (D-IV) atau Sarjana (S1) dalam bidang pendidikan anak usia dini, dan kependidikan lain yang relevan dengan sistem pendidikan anak usia dini, atau psikologi yang diperoleh dari program studi terakreditasi, dan memiliki sertifikat Pendidikan Profesi Guru (PPG) PAUD dari perguruan tinggi yang terakreditasi (Menteri Pendidikan dan Kebudayaan RI, 2014).

Berdasarkan fenomena tersebut maka lembaga PAUD memegang peranan penting dalam mengatur jalannya pendidikan dan pengembangan anak usia dini. Hal ini berkaitan dengan penjaminan kualitas kompetensi guru dalam lembaga tersebut (Pratiwi, 2015). Namun pada kenyataannya peningkatan jumlah lembaga PAUD tidak diimbangi dengan ketersediaan pendidik PAUD yang telah memenuhi kualifikasi akademik. Pandangan terkait kurangnya jumlah pendidik PAUD yang sesuai kualifikasi menjadi tanggung jawab di setiap lembaga masing-masing, dengan demikian penanganan setiap masalah juga berbeda-beda di setiap lembaga menyesuaikan kebijakan yang berlaku di lembaga tersebut.

Guru dikatakan sebagai faktor penentu kualitas pendidikan karena guru memegang peran penuh dalam mencapai tujuan pendidikan. Dengan demikian guru harus memiliki kualitas yang mampu meningkatkan kualitas pendidikan. Kualitas yang perlu dimiliki oleh guru yaitu kualitas akademik, kualitas dalam menguasi kompetensi, serta kualitas menjadi guru profesional (Masruri, 2019). Sama halnya dengan guru di lembaga PAUD yang harus memiliki kualitas agar proses pembelajaran dapat berjalan optimal dan mampu menghasilkan lulusan yang kompetitif. Karena semakin tinggi kualifikasi akademik yang dimiliki akan membuat guru semakin terampil, dengan demikian semakin mudah dalam mencapai tujuan pendidikan anak usia dini (Sugini, 2011). Secara konseptual kualitas yang perlu dicapai oleh setiap guru sama namun berbeda dengan kualitas guru PAUD secara kontekstual, yang lebih merujuk pada perkembangan dan capaian anak usia dini. Linieritas pendidikan guru PAUD 
memengaruhi hal tersebut. Menurut Permendikbud No. 46 tahun 2016 linieritas guru merupakan kesesuaian antara sertifikasi guru dengan bidang yang diampu (Menteri Pendidikan dan Kebudayaan RI, 2016). Sehingga lulusan akademik yang linier dan relevan dengan bidang ilmu PAUD saat ini telah menjadi prioritas. Maka diperlukan adanya peningkatan dan pengembangan kompetensi guru PAUD secara kontekstual, sejalan dengan ditetapkannya peraturan pemerintah dalam persyaratan menjadi seorang guru bersertifikasi.

Beberapa persepsi negatif selalu mengitari profesi guru PAUD seperti status dan gaji guru yang rendah, resiko pekerjaan yang kecil, serta pandangan bahwa guru PAUD tidak memerlukan keahlian khusus membuat masyarakat khususnya laki-laki enggan menyandang profesi ini (Dianita, 2020). Persepsi negatif dan ketidakpahaman inilah yang pada akhirnya membuat mayoritas lembaga PAUD di Indonesia menerima tenaga pendidik yang tidak sesuai disiplin ilmunya demi keberlangsungan pembelajaran PAUD. Sehingga saat ini pendidik PAUD yang seharusnya diisi oleh lulusan linier PAUD seperti S1 PG-PAUD atau PIAUD harus di dominasi oleh lulusan bidang ilmu lain (Ratnawati, 2020).

Rendahnya persentase guru PAUD yang memiliki kualifikasi akademik yang sesuai juga disebabkan oleh jurusan PAUD/PGRA di Indonesia yang tidak terlalu menarik minat masyarakat dan tidak banyak masyarakat yang mengetahui (Surahman et al., 2018). Dengan demikian jurusan PAUD tidak menjadi pilihan utama, cenderung dijadikan sebagai pilihan cadangan dari jurusan lainnya. Begitupun dengan profesi guru PAUD juga kerap kali dijadikan sebagai pilihan cadangan. Anggapan lain juga menyatakan bahwa menjadi guru PAUD cukup sebatas lulusan SMA, masyarakat dapat dengan mudah menjadi guru PAUD. Ketidaktahuan masyarakat dan sosialisasi dari pemerintah yang kurang mengakibatkan persentase guru PAUD berkualifikasi akademik yang sesuai di Indonesia semakin rendah. Sedangkan dalam kualifikasi akademik menjadi guru PAUD harus lulusan yang linier dengan bidang pendidikan anak usia dini dan bidang yang relevan dengan pendidikan anak usia dini. Di sisi lain problematika ini muncul juga disebabkan oleh sumber dana/pembiayaan pendidikan yang semakin menurun di samping bertambahnya jumlah tenaga pendidik (Zulkarnain \& Supriadi, 2021).

Selain itu, rendahnya linieritas guru PAUD juga kerap terjadi dikarenakan stigma maskulinitas-feminitas di masyarakat dan beberapa penyebab lainnya, sehingga telah menimbulkan menurunnya minat pelajar pada profesi ini. Dengan rendahnya linieritas guru PAUD mengakibatkan kualitas guru dalam proses pembelajaran dipertanyakan. Sesuai dengan penelitian sebelumnya bahwa guru PAUD yang tidak linier berdampak terhadap perbedaan kemampuan guru dalam memahami karakteristik anak didik, berpengaruh juga terhadap penyusunan rencana pembelajaran yang sesuai kebutuhan dan perkembangan (Ratnawati, 2020). Selain hal tersebut, kenyataannya memang guru yang tidak linier akan memiliki cara pandang pada peserta didik yang berbeda begitu pula dengan penguasaan kompetensi yang dimiliki, karena pendidikan yang ditempuh sebelumnya tidak terfokuskan pada anak usia dini. Persoalan linieritas tersebut nyatanya selalu menjadi problematika yang selalu dibahas setiap tahunnya pada dunia pendidikan anak usia dini. Untuk meningkatkan profesionalisme kinerja guru PAUD, pemerintah menetapkan standarisasi lulusan akademik harus linier PAUD (Masruri, 2019). Maka setiap lembaga mengambil sikap dan kebijakan yang berbeda-beda disesuaikan dengan problematika yang dimiliki lembaga masing-masing. Kegiatan pengembangan keprofesian berkelanjutan turut menjadi salah satu bentuk upaya peningkatan kualitas guru sesuai perkembangan zaman. Hal ini sesuai dengan Peraturan Pemerintah Nomor 74 Tahun 2008 tentang Guru bahwa pengembangan dan peningkatan kompetensi bagi guru harus sesuai dengan perkembangan ilmu pengetahuan, teknologi, seni, dan budaya/olahraga (Presiden RI, 2008). Penelitian ini dilakukan untuk membahas persoalan mengenai pemenuhan kualifikasi akademik serta linieritas pendidikan akhir dari guru PAUD yang sampai saat ini masih menjadi permasalahan pendidikan di Indonesia, yang berdampak terhadap kualitas kinerja guru yang hal itu sekaligus menjadi jaminan kualitas pendidikan di Indonesia. Penelitian yang telah dilakukan sebelumnya turut menjadi dasar 
sebuah hipotesis bahwa mayoritas linieritas dan pemenuhan kualifikasi akademik guru PAUD di Indonesia tidak berjalan optimal. Problematika pemenuhan kualifikasi dan linieritas pendidikan akhir guru PAUD pada RA Bakti 7 Wonorejo diharapkan dapat dikaji lebih rinci serta mampu diketahui kebijakan yang diterapkan pada lembaga tersebut sebagai upaya mengatasi problematika yang terjadi melalui artikel "Problematika Linieritas dan Pemenuhan Kualifikasi Akademik Guru dalam Lembaga PAUD".

\section{METODOLOGI}

Metode yang digunakan dalam penelitian ini adalah metode kualitatif pendekatan deskriptif yaitu dengan memaparkan hasil data penelitian linieritas lulusan dan pemenuhan kualifikasi guru di RA Bakti 7 Wonorejo. Objek penelitian yaitu para pendidik di lembaga PAUD RA Bakti 7 Wonorejo. Teknik pengumpulan data yang digunakan dalam penelitian ini yaitu kualifikasi, wawancara, dan dokumentasi jenjang pendidikan akhir pendidik linieritas pendidik PAUD di RA Bakti 7 Wonorejo. Alat yang digunakan berupa daftar ceklis untuk menyesuaikan hasil observasi dengan hasil wawancara, daftar ceklis dibuat berdasarkan standar kualifikasi pendidik di Peraturan Menteri Pendidikan dan Kebudayaan Republik Indonesia Nomor 137 tahun 2014 tentang Standar Nasional Pendidikan Anak Usia Dini dan Nomor 46 tahun 2016 tentang Penataan Linieritas Guru Bersertifikat Pendidik.

Analisis data dalam penelitian ini terjadi seiring dengan aktivitas pengumpulan data sampai mengambil kesimpulan. Adapun teknik pemeriksaan keabsahan data dilakukan atas dasar kridebilitas, keteralihan, kebergantungan, dan kepastian yang murni berasal dari penemuan data bukan dari konseptualisasi (Rijali, 2018). Teknik-teknik tersebut menurut Moleong (2000:175-188) antara lain: (1) perpanjangan keikutsertaan di lapangan penelitian, (2) ketekunan pengamatan, (3) triangulasi (Moleong, 2005).

Berikut gambaran dari langkah-langkah dalam penelitian tentang problematika linieritas dan pemenuhan kualifikasi guru di lembaga PAUD RA Bakti 7 Wonorejo

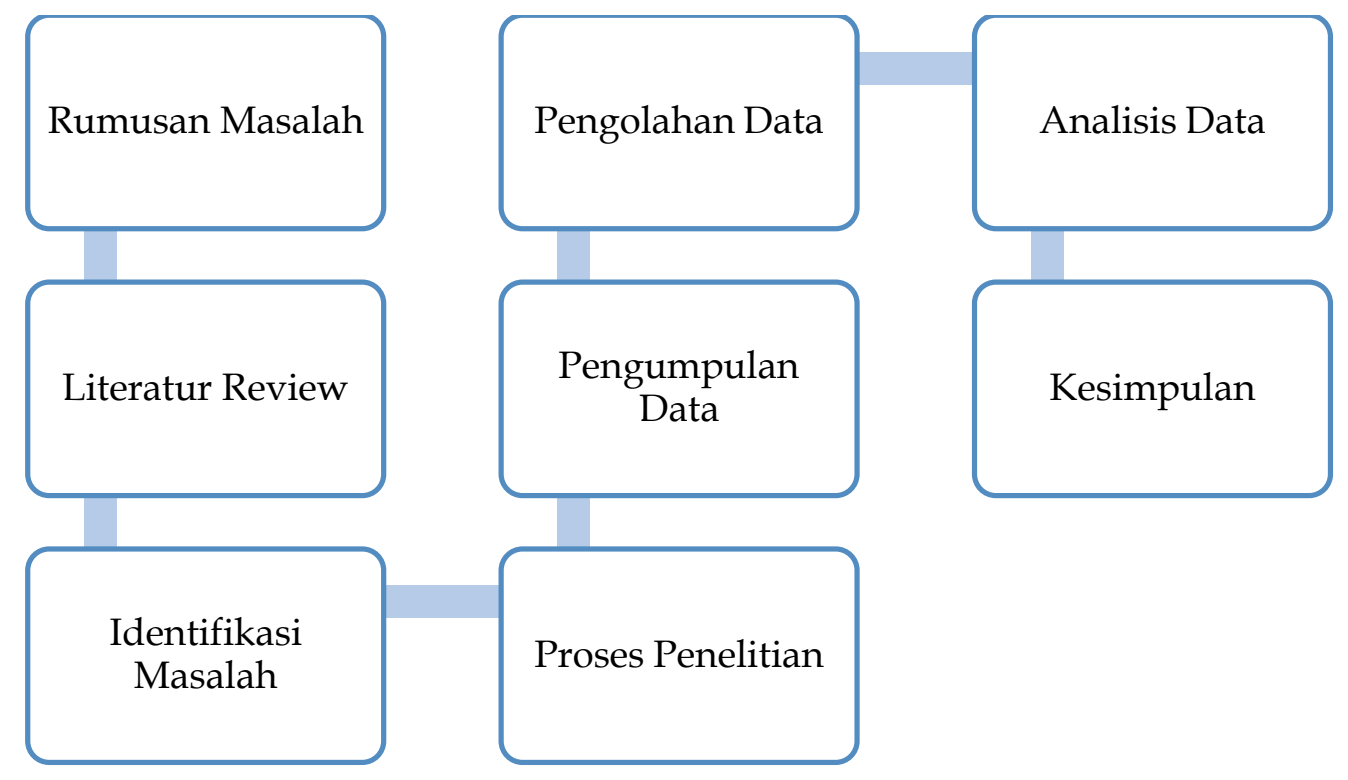

Gambar 1. Bagan Alur Penelitian

\section{HASIL DAN PEMBAHASAN}

\section{Kualifikasi akademik guru PAUD di RA Bakti 7 Wonorejo}

Pendidik anak usia dini dalam Peraturan Menteri Pendidikan dan Kebudayaan RI No. 137 tahun 2014 tentang Standar Nasional Pendidikan Anak Usia Dini terdiri dari guru PAUD, guru pendamping, dan guru pendamping muda (Menteri Pendidikan dan Kebudayaan RI, 2014). Setiap jenis posisi guru tersebut memiliki kualifikasi yang berbeda-beda dikarenakan 
setiap posisi memiliki peran dan tugas yang tidak sama. Guru PAUD merupakan guru yang memegang penuh keberjalanan pembelajaran di kelas sedangkan guru pendamping dan guru pendamping muda menjadi guru bantu bagi guru PAUD di kelas. Kinerja guru sangat dipengaruhi oleh beberapa faktor, seperti kompetensi yang dimiliki, kualifikasi akademik, pelatihan, dan pengalaman mengajar (Andriana et al., 2018). Pentingnya latar belakang lulusan seorang guru sangat memengaruhi kualitas kinerja guru di lapangan sehingga sebagai upaya untuk meningkatkan kualifikasi akademik guru PAUD, saat ini latar belakang lulusan menjadi persyaratan sertifikasi menuju profesionalisme (Sarnoto, 2012). Sertifikasi guru juga harus diimbangi dengan peningkatan kesejahteraan guru, karena tidak dapat dipungkiri bahwa rendahnya kesejahteraan guru akan berdampak terhadap kinerja, pengabdian, serta upaya pengembangan profesionalismenya (Nusa \& Irawan, 2020).

Kualifikasi akademik dapat diartikan sebagai tingkat pendidikan minimal yang harus dipenuhi oleh pendidik. Kualifikasi akademik guru PAUD dalam Peraturan Menteri Pendidikan dan Kebudayaan RI No. 137 tahun 2014 bab VII tentang Standar Pendidik dan Tenaga Kependidikan yaitu memiliki ijazah Diploma empat (D-IV) atau Sarjana (S1) dalam bidang pendidikan anak usia dini, dan kependidikan lain yang relevan dengan sistem pendidikan anak usia dini, atau psikologi yang diperoleh dari program studi terakreditasi, dan memiliki sertifikat Pendidikan Profesi Guru (PPG) PAUD dari perguruan tinggi yang terakreditasi. Berbeda halnya dengan kualifikasi akademik menjadi guru PAUD, kualifikasi akademik yang harus dipenuhi oleh guru pendamping antara lain memiliki ijazah Diploma empat (D-IV) atau Sarjana (S1) dalam bidang pendidikan anak usia dini, dan kependidikan lain yang relevan dengan sistem pendidikan anak usia dini, atau psikologi yang diperoleh dari program studi terakreditasi; atau memiliki ijazah D-II PGTK dari Program Studi terakreditasi. Sedangkan kualifikasi akademik sebagai guru pendamping muda yaitu memiliki ijazah Sekolah Menengah Atas (SMA), dan memiliki sertifikat pelatihan/pendidikan/kursus PAUD dari lembaga pemerintah yang kompeten.

Seperti halnya yang terjadi di RA Bakti 7 Wonorejo yang sampai saat ini guru-gurunya tidak memenuhi standar nasional kualifikasi akademik sebagai pendidik PAUD. Latar belakang pendidikan yang dimiliki guru pada lembaga tersebut tidak berasal dari bidang keahlian yang relevan dengan sistem pendidikan anak usia dini atau dapat dikatakan tidak linier, hal ini yang menjadi dasar permasalahan linieritas dan pemenuhan kualifikasi guru PAUD. Berdasarkan data yang diperoleh di RA Bakti 7 Wonorejo, guru yang dimiliki hanya empat orang untuk 3 kelas. Jumlah guru dan kualifikasi pendidikan yang dimiliki pada lembaga PAUD dapat di klasifikasikan berdasarkan jenjang pendidikan sebagai berikut: jumlah guru yang menempuh pendidikan S1 di luar bidang keahlian sebanyak 2 orang dan S1 pendidikan agama islam sebanyak 2 orang. Walaupun keempat guru di RA Bakti 7 Wonorejo memiliki latar belakang pendidikan S1, namun tidak memenuhi standar nasional klasifikasi akademik yang mengharuskan menempuh bidang yang relevan dengan pendidikan anak usia dini. Pembagian peran guru di RA Bakti 7 Wonorejo dirangkap antara guru kelas dengan administrasi, dilakukan karena kurangnya sumber daya manusia. Pembagian tersebut yaitu satu kepala sekolah dan 3 guru kelas sekaligus tenaga administrasi. Beberapa dampak yang terjadi akibat permasalahan ini yaitu kualitas pendidikan bagi anak di lembaga PAUD. Hal ini sejalan dengan penelitian yang telah dilakukan Julita pada tahun 2018 bahwa kinerja lulusan S1 PAUD lebih baik dari pada lulusan S1 bukan dari PAUD dan lulusan SMA, hasil penelitian tersebut telah ditinjau dari beberapa aspek (Andriana et al., 2018). Sedangkan telah diketahui bahwa linieritas dan pemenuhan kualifikasi akademik guru PAUD di Indonesia bersifat rendah.

\section{Problem guru PAUD di RA Bakti 7 Wonorejo dalam linieritas dan pemenuhan kualifikasi pendidik PAUD}

Problematika linieritas menjadi kebijakan tersendiri yang didukung oleh ditetapkannya Peraturan Menteri Pendidikan dan Kebudayaan Nomor 46 Tahun 2016 bahwa 
setiap guru harus lulusan dari bidang keahlian masing-masing, tak terkecuali pendidik PAUD yang harus lulusan sarjana/ diploma empat dan memenuhi kualifikasi akademik dalam bidang pendidikan anak usia dini. Pengaruh yang diperoleh dengan ada dan tidaknya linieritas bidang pendidikan anak usia dini yaitu cara pandang guru dalam memahami karakteristik anak serta upaya dalam kaitannya dengan penyusunan rencana dan perangkat pembelajaran. Selain itu, linier dan tidaknya lulusan guru PAUD sesuai dengan bidang ilmunya juga berdampak pada pemahaman kode etik guru PAUD, penguasaan kompetensi guru PAUD dan peningkatan mutu pendidikan untuk menyeimbangi persaingan lembaga PAUD internasional (Sarnoto, 2012).

Jumlah guru PAUD di RA Bakti 7 Wonorejo tidak memenuhi standar nasional kualifikasi akademik sebagai guru PAUD. Faktor utama yang mendasari yaitu linieritas yang tidak terpenuhi. Linieritas yang tidak sesuai dengan persyaratan menjadi guru PAUD terpenuhi dibuktikan dengan belum adanya guru yang berasal dari lulusan S1 PG-PAUD atau bidang yang relevan, melainkan berasal dari lulusan kependidikan bidang keahlian lain. Walaupun semua guru PAUD di RA Bakti 7 Wonorejo menyandang gelar sarjana namun linieritas lulusan dari bidang ilmu pendidikan anak usia dini dan bidang relevan lainnya tidak ada pada lembaga ini. Sedangkan dalam Peraturan Menteri Pendidikan dan Kebudayaan RI No. 137 tahun 2014 dijelaskan bahwa pendidikan akhir guru PAUD yaitu Diploma empat (DIV) atau Sarjana (S1) dalam bidang pendidikan anak usia dini, dan kependidikan lain yang relevan dengan sistem pendidikan anak usia dini (Menteri Pendidikan dan Kebudayaan RI, 2014).

Sesuai data penelitian, problematika linieritas lulusan guru PAUD yang tidak sesuai menjadi penyebab tidak terpenuhinya kualifikasi akademik guru. Sehingga dapat dikatakan bahwa linieritas berdampak pada kualifikasi akademik. Penyebab kurangnya persentase guru PAUD yang sesuai kualifikasi akademik di RA Bakti 7 Wonorejo sama dengan lembaga PAUD lainnya yaitu guru PAUD tidak menarik minat masyarakat. Sehingga menjadikan kondisi seperti ini sebagai sesuatu yang tidak dapat dihindari. Di samping itu, pembelajaran di RA Bakti 7 Wonorejo tetap berjalan dengan baik dan lancar bahkan fasilitas pokok dan kebutuhan anak dapat terpenuhi. Fenomena tersebut menunjukkan bahwa kekurangan yang dimiliki tidak menghambat keberjalanan proses pendidikan anak usia dini di RA Bakti 7 Wonorejo. Guru-guru di RA Bakti 7 Wonorejo merupakan lulusan S1 pendidikan atau guru. Walaupun tidak linier dengan bidang ilmu pendidikan anak usia dini, namun tetap memiliki bekal menjadi seorang guru yang selalu mengupayakan pengembangan diri sebagai guru PAUD. Hasil dan pembahasan penelitian ini sejalan dengan penelitian yang telah dilakukan oleh Siti pada tahun 2020 bahwa problematika linieritas dan kualifikasi guru PAUD tidak dapat dicegah walaupun memengaruhi kualitas layanan guru kepada peserta didik namun lembaga memberikan fasilitas terhadap guru untuk mampu pengembangan diri secara mandiri oleh tenaga pendidik dengan penguasaan teknologi (Ratnawati, 2020).

\section{Kebijakan yang diterapkan dalam mengatasi problematika guru PAUD di RA Bakti 7 Wonorejo}

Problematika kualifikasi akademik guru PAUD merupakan permasalahan yang kompleks dan umum terjadi di lembaga PAUD. Upaya penyelesaian masalah setiap lembaga PAUD berbeda-beda menyesuaikan kondisi yang terjadi di lembaga tersebut. Akan tetapi kebijakan yang diberikan oleh lembaga PAUD tidak melanggar peraturan pemerintah. Pada dasarnya RA Bakti 7 Wonorejo lebih mengedepankan tersedianya pendidik PAUD dari pada kualifikasi akademik apabila tidak memperoleh pendidik yang memenuhi standar nasional. Karena pada kenyataannya mencari pendidik berkualifikasi akademik untuk lembaga PAUD yang kecil sukar didapatkan. Sehingga kebijakan inilah yang menjadi poin utama di RA Bakti 7 Wonorejo. Dalam mengatasi problematika kualifikasi akademik guru yang ada di RA Bakti 7 Wonorejo maka lembaga PAUD memberikan kebijakan-kebijakan, yaitu (1) bidang 
pendidikan agama menjadi prioritas, (2) memfasilitasi upaya pengembangan diri sebagai guru PAUD, (3) mengadakan pelatihan mandiri, (4) seminar PAUD, (5) organisasi PAUD.

Pertama, RA Bakti 7 Wonorejo merupakan lembaga PAUD berbasis islam sehingga sesuai kebijakan lembaga, guru-guru dengan lulusan akhir pendidikan agama islam dapat menempati posisi tertinggi yaitu sebagai kepala sekolah di lembaga ini. Kebijakan ini berlaku apabila di RA Bakti 7 Wonorejo tidak memiliki guru yang linier dengan bidang pendidikan anak usia dini atau memiliki kualifikasi akademik. Sehingga dapat dikatakan bahwa kriteria guru yang dimiliki di RA Bakti 7 Wonorejo lebih mengutamakan lulusan yang memiliki kompetensi guru walaupun tidak terkhususkan dalam bidang pendidikan anak usia dini, baik dalam bidang umum maupun bidang agama islam. Trianto (2011) memaparkan bahwa semakin tinggi kualifikasi akademik seorang guru maka akan semakin tinggi pula profesionalisasi profesinya (Aziema et al., 2011). Hal ini sejalan dengan alasan kebijakan tersebut ditetapkan, di RA Bakti 7 Wonorejo menempatkan bahwa lulusan pendidikan agama islam dinilai memiliki kualifikasi lebih tinggi apabila tidak terdapat kualifikasi yang memenuhi standar guru PAUD, sebagaimana sesuai dengan basis lembaga PAUD yaitu islam. Sehingga dianggap layak dijadikan sebagai kepala akademik di RA Bakti 7 Wonorejo. Hal ini sebelumnya pernah dikaji oleh (Kusumawati, 2014) dengan hasil yang menunjukkan bahwa pengangkatan kepala akademik pada PAUD masih berdasarkan anggapan mampu dan tidak mampu sehingga setiap lembaga memiliki standarnya masing-masing, bukan berdasarkan standar nasional dikarenakan tidak adanya guru yang memenuhi standar kualifikasi menjadi guru PAUD.

Kedua, RA Bakti 7 Wonorejo memberikan fasilitas kepada seluruh guru untuk mengembangkan diri sebagai guru PAUD. Upaya pengembangan diri yang dilakukan yaitu mengikuti pelatihan (workshop), pelatihan dasar sebagai guru PAUD, pelatihan pengelolaan data, pelatihan kreativitas guru PAUD, dan lain-lain. Hal ini sesuai dengan penelitian (Rochayadi, 2014) yang memaparkan bahwa kepala PAUD perlu meningkatkan kompetensi guru dengan mengadakan pendidikan dan pelatihan disertai pengembangan dalam bidang tersebut. Selain pelatihan, di RA Bakti 7 Wonorejo juga memberikan kesempatan terhadap seluruh guru untuk berkompetisi. Upaya dalam penguasaan teknologi juga termasuk dalam proses pengembangan diri yang diterapkan. Upaya-upaya pengembangan diri yang diberlakukan di RA Bakti 7 Wonorejo tetap merujuk pada bidang pendidikan anak usia dini dan tujuan diberikannya fasilitas ini sehingga akan berdampak terhadap meningkatnya mutu pembelajaran.

Ketiga, pelatihan mandiri yang dilakukan di RA Bakti 7 Wonorejo yaitu bimbingan internal dengan menghadirkan narasumber yang sesuai dengan topik pembahasan. Pelatihan ini tidak seperti seminar atau acara besar melainkan seperti wawancara, tanya jawab, konsultasi, maupun diskusi sehingga bukan diartikan sebagai acara formal. Kebijakan ini bersifat opsional serta menyesuaikan kondisi. Kebijakan ini relevan dengan penelitian yang telah dilakukan oleh (Ita, 2020) dengan hasil penelitian yaitu guru PAUD yang tidak memenuhi standar kualifikasi diperlukan untuk mengembangkan diri secara berkesinambungan melalui berbagai kegiatan seperti kegiatan ilmiah. Kepala RA perlu memberikan motivasi kepada guru agar dapat berperan aktif di berbagai kegiatan yang mampu meningkatkan kualitas kerja guru di RA Bakti 7 Wonorejo. Walaupun kebijakan ini bersifat opsional namun kepala RA Bakti 7 Wonorejo tetap memberikan pengawasan agar kebijakan yang diterapkan dapat berjalan secara berkesinambungan sebagaimana sesuai dengan tugas kepala akademik.

Keempat, antara seminar dan workshop PAUD memang seringkali disamakan. Namun pada RA Bakti 7 Wonorejo guru dianjurkan untuk mengikuti seminar PAUD dengan materi yang lebih konseptual, seperti pola pembelajaran pada anak usia dini, manajemen kelas, pendekatan pada anak, dan lain-lain. Tujuan pemberian fasilitas guru untuk mengikuti seminar yaitu agar guru memiliki pengetahuan dan pemahaman dalam bidang PAUD secara luas, tidak sebatas pelaksanaan pembelajaran saja melainkan juga merujuk pada bagian 
administrasi dan manajemen PAUD. Hal serupa juga disampaikan oleh (Ats-tsanny, 2020) dalam penelitiannya yang memaparkan bahwa setiap lembaga PAUD perlu memberikan kesempatan terhadap guru untuk mengikuti workshop sebagai upaya membina pendidik PAUD. Pembinaan ini dilaksanakan secara berkala dan bergilir untuk setiap guru di lembaga yang bersangkutan. Sehingga setiap guru di RA Bakti 7 Wonorejo mendapatkan giliran sebagai peserta workshop atau seminar, terkait pelaksanaan secara rinci diatur oleh kepala RA.

Kelima, keberadaan organisasi PAUD turut membantu guru dalam meningkatkan kualitas pendidikan anak usia dini. Salah satunya yaitu HIMPAUDI yang mampu mengembangkan profesi pendidik PAUD, memberikan sosialisasi terkait kualitas PAUD, melakukan pembinaan, dan lain-lain. Penyelenggaraan kegiatan oleh organisasi HIMPAUDI sangat membantu guru-guru dalam mengembangkan pemahaman, kemampuan, serta keterampilan dalam menjadi guru PAUD. Sementara dalam penelitian (Ratnaningsih et al., 2015) menyarankan agar HIMPAUDI yang menjadi mitra mampu mengembangkan kompetensi guru PAUD dengan memberikan pengalaman positif dan wawasan yang luas bagi para pendidik PAUD melalui program kerja. Hal tersebut yang mendasari kepala sekolah RA Bakti 7 Wonorejo memberikan fasilitas ini. Untuk mengenalkan PAUD dan perlahan meluruskan kesalahpahaman yang ada di kalangan masyarakat, HIMPAUDI selalu mengupayakan adanya sosialisasi program PAUD dengan melibatkan masyarakat. Sehingga selain mengatasi masalah pada perangkat PAUD, organisasi PAUD juga berupaya untuk menghilangkan persepsi negatif pada masyarakat (Tedjawati, 2011).

\section{SIMPULAN}

Berdasarkan hasil penelitian dapat disimpulkan bahwa guru-guru di lembaga ini tidak memenuhi standar nasional sebagai guru PAUD karena tidak ada satupun guru yang memiliki lulusan di bidang PAUD atau bidang relevan lainnya. Problematika linieritas dan kualifikasi akademik guru PAUD di RA Bakti 7 Wonorejo secara umum disebabkan oleh rendahnya SDM sebagai guru PAUD. Untuk mengatasi permasalahan tersebut, lembaga menerapkan kebijakan untuk meningkatkan kualitas pendidikan melalui pengembangan diri.

\section{UCAPAN TERIMA KASIH}

Kami sampaikan terima kasih kepada guru di RA Bakti 7 Wonorejo yang telah memberikan kesempatan kepada penulis untuk melakukan penelitian serta memberikan data yang penulis butuhkan. Penulis sampaikan juga terima kasih kepada dosen pengampu yang telah memberikan bimbingan selama proses penyusunan laporan dan pihak-pihak lain yang tidak biasa kami sebutkan satu persatu.

\section{DAFTAR PUSTAKA}

Andriana, J., Sumarsih, \& D, D. (2018). Kinerja Guru Paud Ditinjau Dari Kualifikasi Pendidik, Pengalaman Mengajar, Dan Pelatihan. 3(2), 18-23.

Ats-Tsanny, D. F. (2020). Penerapan Standar Kompetensi Dan Kualifikasi Guru Terhadap Pengelolaan Pendidik Dan Tenaga Kependidikan Di Tk Negeri 2 Yogyakarta. 2(1), 115135.

Aziema, M., R, M., \& Lukmanulhakim. (2011). Pengaruh Kualifikasi Akademik Terhadap Perilaku Terakhir Kepala Tk Beragam Yaitu Dimulai Dari Jenjang Pendidikan Sma Hingga S2 . Hal Ini Menunjukan Bahwa Ada Beberapa Kepala Tk Yang Pendidikan Terakhirnya Belum Memenuhi Standar Kualifikasi Sebagai Kepala. 1-10.

Dianita, E. R. (2020). Stereotip Gender Dalam Profesi Guru Pendidikan Anak Usia Dini. 1(2), 87-105. https:// doi.org/10.35719/gns.v1i2.20 
Esterina, L. (2020). Peran Kepala Sekolah Dalam Meningkatkan Kualifikasi Akademik Guru Paud Di Gugus Mengkudu Kecamatan Karang Tinggi Kabupaten Bengkulu Tengah. $1(1), 55-60$.

Ita, E. (2020). Pengembangan Profesionalitas Guru Pendidikan Anak Usia Dini ( Studi Pada Taman Kanak-. 07, 62-74. https://doi.org/10.38048/jipcb.v7i1.66

Kusumawati, D. (2014). Supervisi Akademik Kepala Sekolah Terhadap Manajemen Pembelajaran Paud (Studi Kasus Di Paud Tunas Bangsa Langensari Ungaran) Desi Kusumawati. 2007, 41-48. https:// doi.org/10.24246/j.sw.2016.v32.i1.p41-48

Masruri, A. (2019). Andragogi Jurnal Pendidikan Islam, Vol 1, No. 2 Tahun 2019 Magister Manajemen Pendidikan Islam Institut Ptiq Jakarta. 1(2), 243-253. https://doi.org/10.36671/andragogi.v1i2.56

Menteri Pendidikan Dan Kebudayaan Ri. (2014). Peraturan Menteri Pendidikan Dan Kebudayaan Republik Indonesia No. 137 Tahun 2014 Tentang Standar Nasional Pendidikan Anak Usia Dini. 1-76.

Menteri Pendidikan Dan Kebudayaan Ri. (2016). Peraturan Menteri Pendidikan Dan Kebudayaan Ri Nomor 46 Tahun 2016 Tentang Penataan Linieritas Guru Bersertifikat Pendidik. 1-4.

Moleong, L. J. (2005). Metodologi Penelitian Kualitatif. Bandung: Remaja Rosdakarya.

Nusa, P. R., \& Irawan, E. (2020). Dampak Sertifikasi Dan Pendidikan Terakhir Terhadap Kinerja Guru Paud Di Kabupaten Ponorogo. 01(01), 27-40. https://doi.org/10.21154/wisdom.v1i1.2134

Pratiwi, F. (2015). Kompetensi Pedagogik Guru Tk Ditinjau Dari Tingkat Pendidikan Guru Di Gugus 1 Anggrek Karanganyar.

Presiden Ri. (2005). Undang-Undang Nomor 14 Tahun 2005 Tentang Guru Dan Dosen (Pp. 1$50)$.

Presiden RI. (2008). Peraturan Pemerintah Republik Indonesia Nomor 74 Tahun 2008 Tentang Guru. 32.

Ratnaningsih, I. Z., Prihatsanti, U., \& Prasetyo, A. R. (2015). Pelatihan Bagi Kader Pendidikan Anak Usia Dini ( Paud ) Kecamatan Banyumanik Semarang. 97-110.

Ratnawati, S. (2020). Problematika Linieritas Pendidikan Guru Anak Usia Dini ( Studi Kasus Di Kelompok Bermain Islam Terpadu ( Kbit ) Al-Ihsaniyah Desa Bangun Galih $\begin{array}{llll}\text { Kecamatan Kramat } & \text { Kebupaten }(02) \text {. }\end{array}$ https://doi.org/10.52266/pelangi.v2i2.581

Rijali, A. (2018). Analisis Data Kualitatif Ahmad Rijali Uin Antasari Banjarmasin. 17(33), 8195. https:// doi.org/10.18592/alhadharah.v17i33.2374

Rochayadi, I. (2014). Upaya Meningkatkan Kompetensi Guru Paud Melalui Pendidikan Dan Pelatihan Guru Di Paud Bougenville Kecamatan Sukajadi Kota Bandung. 4(2252), 1-10.

Sarnoto, A. Z. (2012). Profesionalisme Guru Anak Usia Dini.

Sugini, H. (2011). Hubungan Antara Kualifikasi Akademik Guru Dengan Pola Manajemen Kesiswaan Di Taman Kanak-Kanak Se-Kecamatan Paguyangan.

Surahman, B., Agusmiati, S., \& Andani, F. (2018). Kualifikasi Dan Kuantitas Guru Paud Di Provinsi Bengkulu. 17(1), 29-40. https:// doi.org/10.29300/attalim.v17i1.1178

Tedjawati, J. M. (2011). Peran Himpaudi Dalam Pengembangan Paud. 17(1). https://doi.org/10.24832/ipnk.v17i1.12

Zulkarnain, A. I., \& Supriadi, G. (2021). Jurnal Obsesi : Jurnal Pendidikan Anak Usia Dini Problematika Lembaga Paud Dalam Memenuhi Kebutuhan Tenaga Pendidik Sesuai Kualifikasi Abstrak. 5(1), 14-25. https://doi.org/10.31004/obsesi.v5i1.491 